\title{
ОБГРУНТУВАННЯ ЗАСТОСУВАННЯ СХЕМ МУЛЬТИМОДАЛЬНОЇ АНАЛГЕЗІЇ ДЛЯ ПІСЛЯОПЕРАЦІЙНОГО ЗНЕБОЛЕННЯ У ДІТЕЙ
}

\author{
Д. В. Дмитрієв, Б. В. Залецкий, К. Ю. Дмитрієва \\ Вінницький національний медичний університет імені М. І. Пирогова

\section{SUBSTANTIATION OF APPLICATION OF THE MULTIMODAL ANALGESIA SCHEMES FOR POSTOPERATIVE ANESTHESIA IN CHILDREN}

\author{
D. V. Dmytriyev, B. V. Zaletskiy, K. Yu. Dmytriyeva \\ Vinnytsya National Medical University named after M. I. Pyrogov
}

\begin{abstract}
Реферат
Дослідження проведені у 26 пацієнтів віком у середньому $(17,3 \pm 0,6)$ року, яких оперували з приводу пухлин черевної порожнини - $20(76,9 \%)$ та пухлин яєчника - $6(23,1 \%)$. Залежно від методики знеболення пацієнти розподілені на дві групи, у $14-$ застосована мультимодальна аналгезія, призначали парацетамол 1,5 мг/кг внутрішньовенно за 40 хв до початку оперативного втручання та внутрішньовенну постійну інфузію фентанілу в дозі 5 мкг/(кг × год); у 12 - використовували морфін 10 мг внутрішньом'язово. За даними комплексного вивчення реакцій больової поведінки, фрізіологічних показників і лабораторних стресових тестів, використання мультимодальної аналгезії забезпечує ефективне післяопераційне знеболення у дітей.

Ключові слова: мультимодальна аналгезія; аналгетики; післяопераційне знеболення; діти.

Abstract

The investigation was conducted in 26 patients ageing at average $(17.3 \pm 0.6)$ yrs, who were operated for abdominal tumors -20 $(76.9 \%)$ and ovarian tumors $-6(23.1 \%)$. Depending on the anesthesia procedure applied, the patients were divided into two groups, in 14 - application of multimodal analgesia, there was administered - paracetamol $1.5 \mathrm{mg} / \mathrm{kg}$ intravenously - 40 min before beginning of operative intervention and intravenous constant infusion of phentanyl in $5 \mathrm{mcg} /(\mathrm{kg} \times$ hour) dosage; in 12 - there was applied morphine in dosage $10 \mathrm{mg}$ intramuscular. In accordance to data of complex studying of the pain behavior reaction, physiological indices and laboratory stress tests, application of multimodal analgesia guarantees constitutes an effective postoperative anesthesia in children. Keywords: multimodal analgesia; analgetics; postoperative anesthesia; children.
\end{abstract}

Неадекватна аналгезія в ранньому післяопераційному періоді погіршує його перебіг і прогноз у дітей, збільшує смертність внаслідок підвищення ризику виникнення сепсису, післяопераційних ускладнень, порушення центральної та периферійної гемодинаміки, мезентеріального кровотоку. Біль, що відчуває дитина, змінюе систему ноцицепції, спричиняє необоротні функціональні і структурні зміни в ЦНС, «програму» відповіді на біль у подальшому. Основними причинами неадекватної аналгезії в післяопераційному періоді у дітей є відсутність загальновизнаних і простих методів оцінки вираженості больового синдрому в педіатрії; використання наркотичних аналгетиків в неадекватних дозах, що зумовлює виникнення побічних реакцій; неможливість або обмеження використання ефективних сучасних методів післяопераційної аналгезіі; переконання деяких лікарів, що такі діти менш чутливі до болю. В структурі післяопераційного знеболення у дітей, як і в інших віко- вих групах, основне місце посідають наркотичні аналгетики, шлях введення внутрішньом'язовий, при цьому можливе виникнення неадекватної аналгезії [1 - 8].

Метою цього дослідження було порівняння ефективності та безпеки методів мультимодальної аналгезії з використанням опіоїдних аналгетиків на основі аналізу показників гемодинаміки при оперативних втручаннях $з$ приводу пухлин черевної порожнини у дітей.

\section{МАТЕРІАЛИ I МЕТОДИ ДОСЛІДЖЕННЯ}

Дослідження проведене у 26 пацієнтів віком у середньому $(17,3 \pm 0,6)$ року, оперованих з приводу пухлин черевної порожнини - 20 (76,9\%) та пухлин яєчника - 6 (23,1\%). Залежно від методики знеболення пацієнти розподілені на дві групи. У 14 пацієнтів (1-ша група) застосована мультимодальна аналгезія, призначали парацетамол 1,5 мг/кг внутрішньовенно за 40 хв до початку оперативного втручання та внутрішньовен- ну постійну інфузію фентанілу в дозі 5 мкг/(кг × год); у 12 пацієнтів (2-га група) використовували морфін 10 мг внутрішньом'язово [2, 3, 9].

Всім хворим проведене комплексне інтенсивне лікування: інфузійна та трансфузійна терапія, респіраторна підтримка за допомогою апарата «Hamillton C2» в режимі ASV за параметрами $\mathrm{FiO}_{2}$ 30\%, PEEP 2 см вод. Ст., РІР 15 - 20 см вод. Ст., антибактеріальна терапія, посиндромна терапія. Ефективність знеболення в ранньому післяопераційному періоді оцінювали за візуально-аналоговою шкалою, аналізували частоту дихання (ЧД), частоту скорочень серця (ЧСС), артеріальний тиск систолічний $\left(\mathrm{AT}_{\text {сист. }}\right)$, діастолічний $\left(\mathrm{AT}_{\text {діаст. }}\right)$, середній (САТ), сатурацію кисню $\left(\mathrm{SaO}_{2}\right)$, концентрацію $\mathrm{CO}_{2}$ у

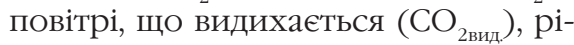
вень кортизолу в крові, перебіг анестезії. Додатково вивчали показники центральної гемодинаміки: ударний об'єм (УО), об'єм кровообігу за 1 хв (ХОК). За даними допплерометрії мезентеріального кровообігу оціню- 
Зміни показників гемодинаміки, пульсоксиметрії та капнометрії на етапах дослідження

\begin{tabular}{|c|c|c|c|c|c|}
\hline \multirow{2}{*}{ Показник } & \multicolumn{5}{|c|}{ Величина показника на етапах дослідження ( $\bar{x} \pm \mathrm{m})$} \\
\hline & 1-му & 2-мy & 3-му & 4-му & 5-му \\
\hline \multicolumn{6}{|c|}{ Перша група } \\
\hline ЧСС, за 1 хв & $132,8 \pm 11,2$ & $124,2 \pm 6,4^{*}$ & $122,4 \pm 5,8^{*}$ & $124,3 \pm 10,2^{*}$ & $128,2 \pm 11,1^{*}$ \\
\hline $\mathrm{AT}_{\text {сист., }}$ Мм рт. ст. & $72,4 \pm 1,4$ & $72,3 \pm 1,2$ & $71,6 \pm 1,4$ & $70,4 \pm 1,4$ & $69,5 \pm 1,4$ \\
\hline $\mathrm{AT}_{\text {діаст., }}$ МM рт. Ст. & $44,4 \pm 1,3$ & $42,2 \pm 1,3$ & $40,4 \pm 1,4$ & $42,4 \pm 1,4$ & $44,2 \pm 1,3$ \\
\hline $\mathrm{SaO}_{2}$, ум. од. & $96,4 \pm 0,4$ & $97,4 \pm 0,2$ & $97,2 \pm 1,4$ & $98,4 \pm 0,2$ & $98,2 \pm 1,4$ \\
\hline УО, мл & $11,1 \pm 1,2$ & $11,2 \pm 1,4$ & $10,9 \pm 1,3$ & $11,3 \pm 1,3$ & $11,4 \pm 1,2$ \\
\hline $\mathrm{XOK,} \mathrm{л}$ & $1,76 \pm 0,2$ & $1,81 \pm 0,2^{*}$ & $1,82 \pm 0,1^{*}$ & $1,74 \pm 0,2$ & $1,68 \pm 0,4$ \\
\hline $\mathrm{CO}_{2, \text { вид., }}$ Мм рт. Ст. & $37,3 \pm 1,4$ & $37,2 \pm 1,2$ & $38,1 \pm 1,1$ & $36,8 \pm 1,2$ & $38,0 \pm 0,9$ \\
\hline \multicolumn{6}{|c|}{ Друга група } \\
\hline पCC, за 1 хв & $134,4 \pm 7,2$ & $154,4 \pm 8,2$ & $148,2 \pm 11,1$ & $152,4 \pm 7,4$ & $143,5 \pm 6,4$ \\
\hline $\mathrm{AT}_{\text {сист. }}, \mathrm{MM} \mathrm{рт.} \mathrm{ст.}$ & $71,6 \pm 1,3$ & $74,0 \pm 1,2$ & $74,4 \pm 1,2$ & $76,0 \pm 1,4$ & $74,0 \pm 1,6$ \\
\hline $\mathrm{AT}_{\text {діact., }}, \mathrm{MM} \mathrm{рт.} \mathrm{ст.}$ & $42,4 \pm 1,4$ & $41,4 \pm 1,4$ & $42,4 \pm 1,4$ & $44,4 \pm 1,4$ & $43,2 \pm 1,4$ \\
\hline $\mathrm{SaO}_{2}$, ум. од. & $96,2 \pm 0,4$ & $96,4 \pm 0,1$ & $96,8 \pm 0,2$ & $97,4 \pm 0,4$ & $98,0 \pm 0,2$ \\
\hline УО, мл & $11,3 \pm 2,1$ & $10,9 \pm 1,4$ & $10,6 \pm 2,0$ & $11,2 \pm 1,4$ & $11,4 \pm 1,2$ \\
\hline $\mathrm{XOK,} \mathrm{л}$ & $1,68 \pm 0,2$ & $1,22 \pm 0,1$ & $1,30 \pm 0,2$ & $1,44 \pm 0,2$ & $1,43 \pm 0,4$ \\
\hline $\mathrm{CO}_{2, \text { вид., }}$ Мм рТ. ст. & $37,2 \pm 0,8$ & $36,9 \pm 1,2$ & $37,6 \pm 1,4$ & $35,9 \pm 1,2$ & $38,8 \pm 1,0$ \\
\hline
\end{tabular}

Примітка. $\quad$ * - різниця показників вірогідна у порівнянні з такими у другій групі $(p<0,05)$.

вали $\mathrm{V}_{\max }, \mathrm{V}_{\min }$, RI у верхній брижовій артерії, максимальну швидкість і характер кровообігу у верхній брижовій вені.

Дослідження проведені 3 використанням апарата Philips HD-7, конвексного датчика з частотою 3,5 - 5,0 МГц, мікроконвексного датчика 3 частотою 4 - 8 МГц в режимі реального часу, дозованої компресії датчиком на передню черевну стінку. Параметри реєстрували в автоматичному режимі за допомогою моніторів «Datascope» та «Novometrix». Дослідження проводили на етапах знеболення: 1-й етап - початок оперативного втручання, 2-й етап - найбільш травматичний момент оперативного втручання, 3-й етап завершення оперативного втручання, 4-й етап - через 6 год після операції, 5-й етап - через 12 год.

Статистична обробка даних проведена з застосуванням методів варіаційної статистики за допомогою програми Statistica 5.5 за стандартною методикою.

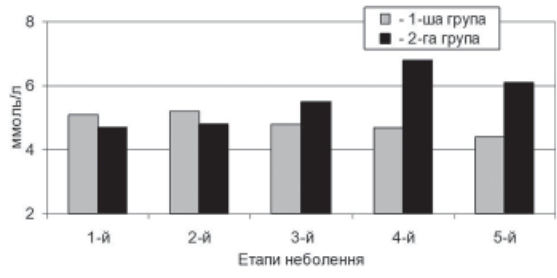

Динаміка рівня кортизолу в крові в групах хворих.

\section{РЕЗУЛЬТАТИ}

Показаннями до введення додаткових болюсів наркотичних аналгетиків були больова поведінка, десинхронізація 3 штучною вентиляцією легень, тахікардія.

В 1-й групі не було необхідності додаткового введення морфіну, у 2-й групі - у 2 (16,6\%) пацієнтів вводили додаткові болюси морфіну 10 мг. Сума балів, що характеризувала вираженість больового синдрому в ранньому післяопераційному періоді, на всіх етапах дослідження (за візуально-аналоговою шкалою) у хворих 1-ї групи була вірогідно меншою ( $\mathrm{p}<0,05)$, ніж у $2-$ й групі.

У 13 (92,8\%) пацієнтів 1-ї групи чСС за весь період знеболення не перевищувала 115 за 1 хв, мінімальна становила $(90,9 \pm 8,2)$ за 1 хв, максимальна - $(117,4 \pm 4,2)$ за 1 хв. АТ $_{\text {сист. }}$ становив $(88,4 \pm 6,2)$ мм рт. ст., АТ $_{\text {діаст. }}$ - $(62,4 \pm 4,4)$ мм рт. ст.

В 2-й групі у більшості - 9 (75\%) пацієнтів ЧСС за весь період введення фентанілу не перевищувала 130 за 1 хв, мінімальна - становила (118,6 \pm $3,3)$ за 1 хв, максимальна - (148,2 \pm 3,4) за 1 хв.

$\mathrm{SaO}_{2}$ під час усього періоду дослідження була стабільною у 98 - 99\% дітей обох груп (див. таблицю).

У більшості пацієнтів виявляли тахікардію з моменту після надходження у відділення з операційної, вона була пов'язана з гіповолемією, інтоксикацією, можливо, неадекватною інтраопераційною аналгезією і зникала після проведення інфузійної терапії та призначення знеболювальних засобів. Вірогідне зменшення на останніх етапах дослідження ЧСС і АТ у пацієнтів 1-ї групи може свідчити про усунення гемодинамічних змін, пов'язаних з основним захворюванням і операцією, досягнення достатнього рівня аналгезії та седації.

Ізольовані гемодинамічні зміни, що свідчили про больовий синдром, виявляли досить рідко. У більшості спостережень вони були короткотривалими, у відповідь на збільшення фізичного навантаження при реакції больової поведінки. При дослідженні артеріального кровообігу у верхній брижовій артерії відзначений високий індекс резистентності в 2-й групі - 0,98 $\pm 0,02$ у 1-й групі $0,82 \pm 0,04$, в нормі 0,6 - 0,8 (p < 0,05), що патогенетично відображало блокаду мікроциркуляторного русла i, як наслідок, неефективне знеболення $[10,11]$.

Найбільш інформативними були показники венозного відтоку по верхній брижовій вені. У дітей 2-і групи виявлена низька максимальна швидкість - до $(22,31 \pm 8)$ см/с, у 1-й групі - $(48,34 \pm 6)$ см/с, що розцінено як недостатня перфузія кишечнику внаслідок недостатнього знеболення $(\mathrm{p}<0,05)$. Рівень кортизолу $є$ 
одним з показників стресової реакції, в тому числі больової, динаміка рівня кортизолу в крові після операції показана на рисунку.

Динаміка рівня кортизолу в крові у хворих 1-ї групи свідчила про усунення у більшості з них протягом 12 - 24 год після операції тяжкого стресу, виникнення якого пов'язане з основним захворюванням або операцією і достатньою аналгезією після операції.

Таким чином, ефективність мультимодальної аналгезії обгрунтована можливістю впливу на центральні й периферійні механізми виникнення болю [12]. Призначення мульти-

\section{REFERENCES}

1. Ayzenberg VL, Ulrikh GE, Tsypin LE, Zabolotskiy DV. Regionalnaya anesteziya v pediatrii. Sintez Buk; 2012. 304 s. [In Russian].

2. Vetshev PS, Vetesheva MS. Printsipy analgezii v rannem posleoperatsionnom periode. Khirurgiya. 2002;(12): 49-52. [In Russian].

3. Osipova NA, Nikoda VV. Sovremennoe sostoyanie nauki o boli. Ostrye i khronicheskie bolevye sindromy. Anesteziologiya i reanimatologiya. 2003;(5): 4-9. [In Russian].

4. Morgan DE Jr, Megid SM. Klinicheskaya anesteziologiya. Moskva: Binom; 2003;(3):298. [In Russian].

5. Karavaeva SA, Bairov VG, Nemilova TK. Lechenie gastroshizisa. Detskaya khirurgiya. 1998;(3):4-7. [In Russian].

6. Zoric S, Stamenkovic D, Stevanovic S, Malenković V, Dikić SD, Randelović $T$, et al. Combined spinal epidural and general anesthesia in abdominal surgery. Med Arh. 2003;57(4):21-8.

7. Kopacz DJ, Allen HW, Thompson GE. A comparison of epidural levobupivacaine $0.75 \%$ with racemic bupivacaine for lower abdominal surgery. Anesth Analg. 2000;(90):642-8. ефективну аналгезію після оперативного втручання у дітей.

2. Застосування мультимодальної аналгезії значно зменшує негативні наслідки недостатнього знеболення у пацієнтів, оперованих з приводу пухлин черевної порожнини, доцільне для ведення післяопераційного періоду.

3. При використанні мультимодальної аналгезії покращуються показники центральної та мезентеріальної гемодинаміки у пацієнтів, оперованих 3 приводу пухлин черевної порожнини, знижується ризик виникнення ускладнень.
8. Hopf $\mathrm{H}$, Weitz J. Postoperative pain management. Arch Surg 1994.129(2):128-32.

9. Lekmanov AU. Vnutrivennoe ispolzovanie tramadola dlya posleoperatsionnoy analgezii u detey. In: Materialy VIII Vserossiyskogo s'ezda anesteziologov reanimatologov. 1999:14-17. [In Russian].

10. Vasilev AYu, Olkhova EB. Ultrazvukovaya diagnostika v neotlozhnoy detskoy praktike. Rukovodstvo dlya vrachey. Moskva: Izdatelskaya gruppa GEOTAR-Media; 2010. [In Russian].

11. Lepikhov PA, Turpakova GN. Ekhografiya v differentsialnoy diagnostike abdominalnykh boley u detey. Promeneva diagnostika, promeneva terapiia. 2012;(1):55-71. [In Russian].

12. Brennum J, Petersen KL, Horn A, Arendt-Nielsen L, Secher NH, Jensen TS. Quantitative sensory examination of epidural anaesthesia and analgesia in man: combination of morphine and bupivacaine. Pain. 1994;56:327-37. 